\title{
Assessing the influence of total quality management practices on innovation in Jordanian manufacturing organizations
}

\author{
Sultan Alshourah ${ }^{\text {** }}$ \\ ${ }^{a}$ Assistance professor of Business Department, College of Economics and Administrative Sciences, Zarqa University, Zarqa, Jordan

\section{CH R O N I C L E}

\section{A B S T R A C T}

Article history:

Received September 2, 2020

Received in revised format

November, 18, 2020

Accepted December 72020

Available online

December 72020

Keywords:

$T Q M$

Innovation

Product and process

innovation

Jordan manufacturing

organizations sector
The purpose of this study is to assess the influence of total quality management (TQM) dimensions on the product and process innovation perspectives of Jordanian manufacturing organizations. In this quantitative study; a questionnaire was sent to 249 randomly selected ISO 9001:2000 certified firms in different manufacturing industries in Jordan and we obtained 123 usable questionnaires. After confirming the validity and reliability of the latent variables with confirmatory and exploratory factor analyses, we examined the model and hypotheses. This search outcome confirmed the significant and positive relationship between TQM dimensions overall and product and process innovation perspectives. However, the supplier's management failed to show a significant relationship with product and process innovation perspectives. Meaningful implications are made that building extensive and effective TQM dimensions and product and process innovation in manufacturing organizations is crucial to face with high competition and innovation in Jordan manufacturing organizations sector.

(C) 2021 by the authors; license Growing Science, Canada

\section{Introduction}

Jordan is among the top 10 performers in the World Bank's Doing Business 2020 report (Business, 2020). The Jordanian manufacturing sector plays an important role in Jordan's economic growth and contributes about \%24.5 to the Jordanian GDP, however, the performance of this sector has been declining since 2010 (Ministry of Industry and Carpentry). According to the World Bank report (2020), the impact of the Corona pandemic on the global economy is likely to weaken Jordan's economic growth prospects to a noticeable degree in the near term. However, a gradual economic recovery in the medium term could benefit from lower oil prices and continued momentum of economic reforms. The competitiveness of Jordanian manufacturers remains below the required level (Council, 2018). According to Jordan's economic growth plan (2018-2022), the sector was also affected by other factors such as intense competition from other countries (such as Turkey and the Gulf countries), increased cost, and lower demand. Besides, unstable countries like Iraq and Syria showed a sharp drop in demand. Therefore, companies must face competition, developing Jordanian industrial products, encouraging creativity and innovation, improving the quality of local products, adapting them to international standards, and increasing their competitiveness to enhance their innovative performance (Council, 2018). Organizations must implement strategies that can help them overcome these obstacles (Alshourah, 2020). These practices may include the implementation of TQM strategies that are appropriate strategies in such a situation, an innovation that has always been an important tool for enhancing organizational performance and survival and reducing cost for market survival and competition (Abdallah, 2013; Abdallah et al., 2019; Abu-Salim et al., 2019; Allan et al., 2018; Krajcsák, 2019). According to Kim et al., (2012), innovation has an important role in providing and improving the provision of unique products and services, creating greater value to manufacturing organizations, and identifying barriers that may prevent the entry of new competitors. For this reason, the topic of innovation has aroused an increasing interest among many researchers and scholars to identify push factors, and another issue that has been taken into consideration is whether TQM practices may emerge as a condition for defining innovation strategies and creating an innovative environment in organizations (Abrunhosa et al., 2008; Alshourah, 2020;

* Corresponding author

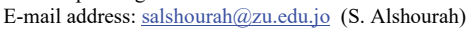

(C) 2021 by the authors; licensee Growing Science. doi: $10.5267 /$ j.uscm.2020.12.001 
Mahmud et al., 2019). However, from previous studies, contradictory ideas can be found, which is why there is no consensus on whether TQM dimensions help create an environment and culture that supports innovation (Alshourah, 2020; Mahmud et al., 2019). In addition, TQM has become one of the major developments and a revolutionary concept in the field of management practices. Moreno-Luzon et al. (20013) argued that although the topic of TQM dimensions has been extensively researched and generated a great deal of literature, it remains open to new perspectives.

Many researchers have emphasized the importance of implementing total quality management practices to create an innovative environment for launching new development products and services to meet customer requirements (Antunes et al., 2018; Arrfou, 2019; Jiménez-Jiménez et al., 2019; Kafetzopoulos et al., 2015; Kanji, 1996; Taddese, 2017; Yusr et al., 2017). However, the numerous studies that have been conducted on the innovation of TQM in various industries, there is still considerable disagreement about their results especially in Manufacturing Organizations (Arrfou, 2019; Krajcsák, 2019; Manders et al., 2016). On the other hand, there is general agreement among research studies on the importance of this topic, as well as that there is a lot of space for further research in the field of quality management and innovation. (Palm et al., 2014) recommended further future research on how to develop quality management strategies in order to motivate and improve innovation. Kim et al. (2012) pointed out that the need more for studies to investigate the relationship between TQM and innovation in both ISO 9001 certified and non-certified corporations. While Martinez-Costa and MartinezLorente (2008) advocate additional study on quality management and the way it affects both product and process innovation. Finally, Prajogo and Sohal (2006) pointed out that a number of few studies have focused on investigating the relationship between TQM and innovation, which leads to more efforts to examine this relationship. Therefore, the contribution of TQM to innovation has not been explored sufficiently in previous research (El Manzoni et al., 2019; Jiménez-Jiménez et al., 2019; Prajogo \& Sohal, 2004, Riello, 2014 Yusr et al., (2017), especially, the literature review reveals that studies in the Jordanian manufacturing organizations are lack (Abdallah et al., 2013). Therefore, the reason for this search was to examine the impact of TQM on the product and process innovation of Jordanian manufacturing organizations.

From the above arguments, it is evident that studying the relationship between TQM, product innovation and the innovation process is essential. Such a study needs to provide manufacturing organazations with a theoretical and practical platform in order to gain sustainable competitive advantages and enhance performance. As such, the study aims for this search are:

- To explore the relationship between TQM dimensions and product and process innovation; and

- To identify the TQM dimensions that has contributed significantly to product and process innovation.

\section{Literature review}

\subsection{TQM Dimensions}

Quality management is "a comprehensive management philosophy that enhances all functions of an organization through continuous improvement and organizational change" (Arrfou, 2019). International Organization for Standardization (ISO) definition of Total Quality Management. It is a management approach of a quality-centered organization based on the participation of all members and aims at long-term success through customer satisfaction and benefits for all members of the organization and society. It is a philosophy committed to customer satisfaction and continuous improvement. In relation to innovation, Kim (2012) defined it as "the management of all activities involved in the process of generating ideas, developing technology, manufacturing and marketing a new (or improved) product or manufacturing process or equipment". Quality management "captures features from distinct organizational models and extends them by introducing principles, methodologies, and techniques" (El Manzani et al., 2019; López-Mielgo et al., 2019). However; for three decades, Total Quality Management has been one of the most popular and enduring concepts of management. Total Quality Management has attracted scholars due to its increasing prevalence and acceptance in the business world. However, due to the lack of a standard definition of TQM, the definition of TQM is very problematic. In addition, there is a lack of agreement among academics about the definition and meaning of TQM (Camisón Costa et al., 2008; Di Benedetto et al., 2008; El Manzani et al., 2019; Kim et al., 2012; Zehir et al., 2012).

The researcher has collected studies published in reputable scientific journals and experimental work on TQM and innovation types over the past twenty years approximately in the manufacturing industry as shown in Table 2.It is clear from the table that several attempts have been made to define the main dimensions of TQM, explaining their importance and linking them with innovation. For example; Al-Yusr (2017) emphasizes that industrial companies need to support the successful implementation of the TQM and innovation dimensions. Hong et al. (2011) also emphasized that quality management is not only a management tool for improving and enhancement quality, it can also promote a culture of engagement, openness, trust, and innovation when it is reinforced by top management. According to Escrig-Tena et al. (2018), their findings, Total Quality Management factors stimulate innovation in ISO 9001 certified companies in high technology manufacturing. Moreover, a similar study by Taddese, (2017) He pointed out that quality management facilitates the process of developing and promoting innovation in organizations through coordinated and integrated applications of administrative processes and among interconnected innovation initiatives, which also represent their response to different market needs. Sahoo notes, (2020) that a firm's ability to manage and design product quality is a critical capacity for both 
product and process innovation. High-quality product capacity design can be an important key component of product innovation, ensuring a faster and more effective translation of new ideas into product features and technical specifications that value customer requirements. Meanwhile, Antunes et al (2018) also support the argument that organizations implementing TQM will be successful in identifying innovative strategies. Therefore, the nature of the relationship between TQM and innovation remains a matter of great debate. Furthermore, some researchers found that the relationship is positive while others indicate otherwise.

Based on the review of previous studies as shown in Table 2 which clarifies the dimensions of TQM and what are the Dimensions measures for the success of TQM. In addition, there are no consistent, reliable standards in implementing TQM in manufacturing organizations. In other meaning; there are no consistent dimensions regarding the impact and application of TQM in manufacturing organizations. Therefore, in this study, a number of these measures can be measured through six general categories of measures including "top management; Customer Focus; People Management; processes Management, Suppliers Support, and Design of product”. Table 1 explains these metrics definitions and literature support.

Table 1

Definition and Support for previous studies Related with TQM dimensions

\begin{tabular}{|c|c|c|}
\hline Dimensions & Definition & Support for previous studies \\
\hline Top management & $\begin{array}{l}\text { It is related to top management's commitment to quality } \\
\text { management culture }\end{array}$ & $\begin{array}{l}\text { Yusr et al., (2017), Singh \& Smith, (2004), Jiménez- } \\
\text { Jiménez et al., (2019), El Manzani et al., (2019) }\end{array}$ \\
\hline Customer Focus & $\begin{array}{l}\text { It relates to how the organization defines therequirements, } \\
\text { needs, expectations, and preferences of clients }\end{array}$ & $\begin{array}{l}\text { Kanapathy et al., (2017), Taddese (2017) } \\
\text { Camisón \& Puig-Denia, (2016), Ooi et al., (2012) }\end{array}$ \\
\hline People Management & $\begin{array}{l}\text { It is related to the way in which the organization engages } \\
\text { the employees and encourages their participation and } \\
\text { commitment to the activities of the organization }\end{array}$ & $\begin{array}{l}\text { Sahoo, (2020), Antunes et al., (2018), Prajogo\& Hong } \\
\text { (2008), Kanapathy et al., (2017) }\end{array}$ \\
\hline ProcessesManagement & $\begin{array}{l}\text { It is related to reviewing the operations of theorganization, } \\
\text { with the aim of continuous improvement. }\end{array}$ & $\begin{array}{l}\text { Yusr et al., (2017), Antunes et al., (2018), Taddese, } \\
\text { (2017), Kim et al., (2012), Prajogo \& Hong, (2008) } \\
\text { Maistry et al., (2017), El Manzani et al., (2019) }\end{array}$ \\
\hline Suppliers Support & It relates to how the organization relates to its suppliers & $\begin{array}{l}\text { Singh \& Smith, (2004), Prajogo\& Hong (2008) } \\
\text { Prajogo \& Sohal, (2004), Maistry et al., (2017) }\end{array}$ \\
\hline Design of product & $\begin{array}{l}\text { It relates to the use of quality tools and techniques in } \\
\text { product design and development }\end{array}$ & $\begin{array}{l}\text { Kanapathy et al., (2017), Antunes et al., (2018) } \\
\text { Sahoo, (2020) }\end{array}$ \\
\hline
\end{tabular}

Table 2

Summarize the past experimental studies on the relationship between TQM and innovation dimensions

\begin{tabular}{|c|c|c|c|c|}
\hline Authors & TQM Dimensions & Innovation perspectives & Method & Finding \\
\hline Yusr et al. (2017) & $\begin{array}{l}\text { leadership management commitment, customer } \\
\text { focus, quality data reporting, processes } \\
\text { management, people management, supplier } \\
\text { quality Management }\end{array}$ & $\begin{array}{l}\text { Rate of innovation of new } \\
\text { operational processes } \\
\text { Rate of introduction of new } \\
\text { products }\end{array}$ & $\begin{array}{l}\text { Nanufacturing firms } \\
\text { in Malaysia }\end{array}$ & Not supported \\
\hline Sahoo, (2020) & $\begin{array}{l}\text { Cross-functional product design, Organization- } \\
\text { wide employee, Quality empowerment, Training, } \\
\text { Quality information usage }\end{array}$ & $\begin{array}{l}\text { Process quality \&Product } \\
\text { qualityinnovation }\end{array}$ & $\begin{array}{l}\text { Indian } \\
\text { manufacturing }\end{array}$ & Supported \\
\hline $\begin{array}{l}\text { Singh \& Smith, } \\
\text { (2004) }\end{array}$ & $\begin{array}{l}\text { leadership, customer focus, employee inter- } \\
\text { relationships, information/ communication } \\
\text { systems, management of processes \& products, } \\
\text { relations with suppliers }\end{array}$ & $\begin{array}{l}\text { Technological innovation: } \\
\text { (processes/products/services } \\
\text { innovation) }\end{array}$ & $\begin{array}{l}\text { Manufacturing } \\
\text { firms in Australia }\end{array}$ & Not Supported \\
\hline $\begin{array}{l}\text { Antunes et al., } \\
(2018)\end{array}$ & $\begin{array}{l}\text { Leadership, Customer Focus, Benchmarking, } \\
\text { Employee Involvement, Development / Training, } \\
\text { Quality / Product Design, Measurement of the } \\
\text { results, Continuous Improvement }\end{array}$ & $\begin{array}{l}\text { Product \& Process } \\
\text { Innovation }\end{array}$ & $\begin{array}{l}\text { Manufacturing } \\
\text { small and medium- } \\
\text { sized Portuguese } \\
\text { companies }\end{array}$ & Not Supported \\
\hline $\begin{array}{l}\text { Hoang } \\
\text { \&Laosirihongthong, } \\
(2006)\end{array}$ & $\begin{array}{l}\text { Top management commitment, Employee } \\
\text { empowerment, Employee involvement, } \\
\text { Education and training, Teamwork Open } \\
\text { organization, Customer focus, Process } \\
\text { management, Information and analysis system, } \\
\text { Strategic planning. }\end{array}$ & $\begin{array}{l}\text { Actual innovation } \\
\text { output(number of new } \\
\text { products, commercialized } \\
\text { over the last three years and } \\
\text { its level of newness }\end{array}$ & $\begin{array}{l}\text { Vietnam, } \\
\text { Manufacturing } 47 \% \\
\text { of the sample, } 17 \% \\
\text { of services }\end{array}$ & $\begin{array}{l}\text { Supported } \\
\text { Not all QM } \\
\text { practices } \\
\text { enhance } \\
\text { innovation. }\end{array}$ \\
\hline Taddese (2017) & Human, information, and technology factors. & $\begin{array}{l}\text { process \& product } \\
\text { innovation }\end{array}$ & $\begin{array}{l}\text { Different industries } \\
\text { Japan, India, and } \\
\text { Thailand countries }\end{array}$ & Supported \\
\hline Kim et al., (2012) & Process management, Quality data and reporting. & $\begin{array}{l}\text { Product and processradical, } \\
\text { product, processincremental, } \\
\& \text { administrative innovation }\end{array}$ & $\begin{array}{l}\text { Canada, } \\
\text { manufacturing or } \\
\text { service firms }\end{array}$ & Supported \\
\hline $\begin{array}{l}\text { Prajogo \& Hong } \\
(2008)\end{array}$ & $\begin{array}{l}\text { Leadership, people management, and process } \\
\text { management, information \& analysis, customer } \\
\text { focus, , strategic planning. }\end{array}$ & Product innovation & $\begin{array}{l}\text { R\&D divisions of } \\
\text { manufacturing firms } \\
\text { in South Korea }\end{array}$ & Supported \\
\hline Moura et al. (2007) & $\begin{array}{l}\text { Internal communication, Autonomy, } \\
\text { consultation, qualitative flexibility, formalization. }\end{array}$ & Innovation of technological & $\begin{array}{l}\text { footwear } \\
\text { manufacturing firms } \\
\text { in Portugal }\end{array}$ & Not Supported \\
\hline $\begin{array}{l}\text { Santos-Vijande \& } \\
\text { Álvarez-González, } \\
(2007)\end{array}$ & $\begin{array}{l}\text { Leadership, partnership, processes, policy \& } \\
\text { strategy, resources, and people. }\end{array}$ & $\begin{array}{l}\text { Product \& service } \\
\text { innovations, production } \\
\text { processes or service } \\
\text { operations innovation. }\end{array}$ & $\begin{array}{l}\text { manufacturing and } \\
\text { service firms in } \\
\text { Spain }\end{array}$ & Not Supported \\
\hline
\end{tabular}


Table 2

Summarize the past experimental studies on the relationship between TQM and innovation dimensions (Continued)

\begin{tabular}{|c|c|c|c|c|}
\hline Authors & I Dimensions & Innovation perspectives & Method & Finding \\
\hline $\begin{array}{l}\text { Kanapathy et al., } \\
\text { (2017) }\end{array}$ & $\begin{array}{l}\text { Soft TQM: Top management support (Employee } \\
\text { training Employee involvement Hard TQM: } \\
\text { quality information usage, customer orientation, } \\
\text { process/product design, and supplier quality, } \\
\text { Quality information availability }\end{array}$ & $\begin{array}{l}\text { Process innovation } \\
\text { Product innovation }\end{array}$ & $\begin{array}{l}\text { manufacturing sector } \\
\text { in Malaysia }\end{array}$ & $\begin{array}{l}\text { Supported Soft } \\
\text { TQM } \\
\text { Not Supported } \\
\text { with Hard } \\
\text { TQM: }\end{array}$ \\
\hline $\begin{array}{l}\text { Camisón \&Puig- } \\
\text { Denia, (2016) }\end{array}$ & $\begin{array}{l}\text { Quality management, . Product quality, Service } \\
\text { quality, Quality assurance }\end{array}$ & process innovation & $\begin{array}{l}\text { Spanish industrial } \\
\text { companies }\end{array}$ & Not Supported \\
\hline Ooi et al., (2012) & $\begin{array}{l}\text { Leadership, Process Management, Customer } \\
\text { Focus, People Management, Strategic Planning, } \\
\text { Information Analysis }\end{array}$ & $\begin{array}{l}\text { Process innovation } \\
\text { Product innovation }\end{array}$ & $\begin{array}{l}\text { manufacturing firms } \\
\text { in Malaysia }\end{array}$ & Supported \\
\hline $\begin{array}{l}\text { Moreno-Luzon et al., } \\
\text { (2013) }\end{array}$ & processes, people and customers & $\begin{array}{l}\text { radical innovation \& } \\
\text { incremental innovation }\end{array}$ & $\begin{array}{l}\text { Spanish (Valencia } \\
\text { region) furniture and } \\
\text { textile sectors }\end{array}$ & $\begin{array}{l}\text { Not Supported } \\
\text { with } \\
\text { Supported with }\end{array}$ \\
\hline $\begin{array}{l}\text { Jiménez-Jiménez et } \\
\text { al., (2019) }\end{array}$ & $\begin{array}{l}\text { Leadership, Quality training, Suppliers selection } \\
\text { based on quality criteria, Tools for quality } \\
\text { improvement, Continuous improvement } \\
\text { activities }\end{array}$ & $\begin{array}{l}\text { product innovation } \\
\text { process innovation } \\
\text { administrative innovation }\end{array}$ & $\begin{array}{l}\text { Spanish, } \\
\text { (Approximately } 58 \% \\
\text { of the sample } \\
\text { manufacturing } \\
\text { industries) }\end{array}$ & Not Supported \\
\hline Prajogo\&Sohal(2004) & $\begin{array}{l}\text { Leadership, customer focus, people } \\
\text { management, information \& analysis, process } \\
\text { management, , strategic planning. }\end{array}$ & Innovation of Product & $\begin{array}{l}194 \text { manufacturing } \\
\text { and non- } \\
\text { Manufacturing } \\
\text { companies } \\
\text { inAustralia } \\
\text { SME }\end{array}$ & Not Supported \\
\hline Hoang et al., (2006) & $\begin{array}{l}\text { Top management commitment, process } \\
\text { management, employee empowerment, } \\
\text { teamwork, education \& training, service culture, } \\
\text { customer focus, employee involvement, } \\
\text { information and analysis system, strategic } \\
\text { planning and open organization. }\end{array}$ & Innovation output & $\begin{array}{l}204 \text { manufacturing } \\
\text { and service firms in } \\
\text { Vietnam } \\
\text { SME }\end{array}$ & Supported \\
\hline $\begin{array}{l}\text { Perdomo-Ortiz et al., } \\
(2006)\end{array}$ & $\begin{array}{l}\text { Management support, information for quality, } \\
\text { process management, product design, human } \\
\text { resource management, and relationship with } \\
\text { customer and suppliers. }\end{array}$ & Innovationof business & $\begin{array}{l}102 \text { machinery and } \\
\text { instruments } \\
\text { businesses in Spain }\end{array}$ & Supporting \\
\hline $\begin{array}{l}\text { Santos- } \\
\text { Vijande\&Álvarez- } \\
\text { González, (2007) }\end{array}$ & $\begin{array}{l}\text { Leadership, people, policy and strategy, } \\
\text { processes and resources, and partnership. }\end{array}$ & $\begin{array}{l}\text { innovation: Technical, } \\
\text { service operations, } \\
\text { Administrative, } \\
\text { managerial and marketing } \\
\text { innovations }\end{array}$ & $\begin{array}{l}93 \text { ISO } 9000 \text { certified } \\
\text { firms (manufacturing } \\
\text { and service) in Spain, } \\
\text { SEM }\end{array}$ & Not Supported \\
\hline $\begin{array}{l}\text { Abrunhosa et al., } \\
(2008)\end{array}$ & $\begin{array}{l}\text { Autonomy, consultation, communication, } \\
\text { supportive people management practices and } \\
\text { qualitative flexibility. }\end{array}$ & $\begin{array}{l}\text { Process-based } \\
\text { technological innovation }\end{array}$ & $\begin{array}{l}20 \text { footwear } \\
\text { manufacturing firms } \\
\text { in Portugal, SEM. }\end{array}$ & Supported \\
\hline Maistry et al., (2017) & $\begin{array}{l}\text { Stakeholders focus, Training, top management } \\
\text { commitment and leadership. Teamwork, } \\
\text { Employee involvement, Supplier/partnership } \\
\text { Management, Communication, Employee } \\
\text { appraisal, Quality culture. Employee satisfaction. } \\
\text { Social responsibility, Continuous improvement }\end{array}$ & $\begin{array}{l}\text { Innovation: } \\
\text { Administrative } \\
\text { and technological } \\
\text { Innovation }\end{array}$ & $\begin{array}{l}100 \text { persons holding } \\
\text { top and middle-level } \\
\text { management } \\
\text { positions in } \\
\text { government funded } \\
\text { agricultural R\&D } \\
\text { Organizations. }\end{array}$ & Support \\
\hline $\begin{array}{l}\text { El Manzani et al., } \\
(2019)\end{array}$ & $\begin{array}{l}\text { Social (Leadership, Involvement of people, } \\
\text { customer focus, supplier relationships) and } \\
\text { Technical (Continuous improvement, Process } \\
\text { approach, System approach to } \\
\text { management, Factual approach to } \\
\text { decision making) QMs }\end{array}$ & product innovation & $\begin{array}{l}\text { a quantitative data } \\
\text { from } 82 \text { Moroccan } \\
\text { certified ISO } 9001 \\
\text { firm (manufacturing } \\
\text { and service) }\end{array}$ & Not Supported \\
\hline
\end{tabular}

\subsection{Innovation types}

Innovation is defined as: "the adoption of an internally generated or purchased device, system, policy, program, process, product, or service that is new to the adopting organization" (Damanpour, 1991). There is an agreement among previous studies about the expected benefits if organizations pursue an innovation strategy. These benefits and advantages include increased market share, increased market share, improved production efficiency, improved performance, responding to customer feedback, and creative response to intense competition. When reviewing previous international research on innovation; it was revealed that there are many different approaches to classifications of innovation, while the limits of definition are usually not very indeterminate. Table 2 shows the elements of the types of innovation in different settings and countries in which the studies were conducted. In terms of measuring innovation; there is general agreement on two indicators, product, and process innovation. Therefore, this search considered that technical innovation includes both product and process innovation. Product innovation is defined as "new products or services introduced to meet an external user or market need" (Li et al., 2012; Shan et al., 2016). It is related to ever-changing customer needs, new technologies, short product life cycles, and increasing global competition (Gunday et al., 2011). Process innovation is defined "as changes in the method of producing products or services" (Gunday et al., 2011; Forsman, 2011; Prajogo et al., 2008). In most studies, 
process innovation is related to the sequence and nature of the production process which improves the productivity and efficiency of production activities (Garcia \& Calantone, 2002; Pekovic \& Galia, 2009).

\subsubsection{The positive relationship between TQM and innovation}

Past studies argue that practices of TQM, in their human and technological dimensions, help create an environment and culture that supports innovation (Hoang et al., 2006; Prajogo \& Sohal, 2003b; Feng et al., 2006). For example, in their investigation on the 12, Vietnamese industry companies that had been ISO 9001 certified, Thai Hoang et al. (2006) confirmed that "leadership and people management, process and strategic management, and open organization" showed a significant impact on the company's innovativeness. In a survey of 194 managers in Australia who worked in both manufacturing and non-manufacturing companies, Prajogo and Sohal (2004) found that TQM had a significantly positive relationship with both product quality and product innovation performance, although the magnitude of the relationship appeared to be greater against the product quality. For in three industries across eight countries, Survey data were collected from 238 plants by Zeng et al. (2016) results which indicate that Process Management, Quality information, influences the speed of new product introduction, while it's on product innovativeness, not influences. Moreover, Small group problem, training for employees, Task-related, Employee suggestion directly influences product innovativeness. But, it's on new product introduction indirectly influences. 190 organizations from both manufacturing and service industries in the United Arab Emirates (UAE) were studied by Abu Salim et al. (2019) found that continuous improvement, human resource management, and information measurement were positively linked to innovation. 500 ISO 9001:2000 certified firms in different industries in Turkey study conducted by Sadikoglu and Zehir. (2010) found no negative effect of TQM practices on innovation, in fact, the contrary is the case: successful TQM efforts improve the performance of the firm in terms of radical innovation. According to Escrig-Tena et al., (2019), The findings from structural equation modeling show the direct influence of the hard QM dimensions (Benchmarking, Zero-defects mentality, Process improvement, Measurement, Leadership) on product and process innovation in the high technology manufacturing and service sectors. Using a selfadministered survey of a sample from Taiwanese high-tech industry companies by Hung et al. (2011) shows that TQM has significant and positive impacts on innovation performance. They assert that the elements of total quality management motivate employees to improve products, processes, and performance of organizational innovation. Escrig-Tena et al. (2018) found that both hard and soft factors motivate innovation in the ISO 9001 certified firms in high technology manufacturing and service sectors. However, according to their findings, soft practices encourage this through proactive behaviors, such as employee initiatives and ideas that are generated if there is an environment of trust in the organization. A similar positive influence of three factors of TQM (human factor, technology factor, and information factor) on relationship process innovation and product innovation was found by Taddese (2017), in their study in Japan, India, and Thailand countries across the fourteen industries. The search findings indicate that TQM facilitates the development of innovation capabilities in organizations through harmonized management practices in a sequence of inter-related incremental innovation initiatives and it's also its response to different market needs. A quantitative study conducted 134 Indian manufacturing by Sahoo, (2020) found that Supported relationship QM elements and performance as process and product design quality. TQM dimensions persuade the definition of innovation strategies of products and processes within manufacturing organizations.

\subsubsection{The negative relationship between TQM and innovation}

Although evidence of such a positive impact on innovation is accepted, negative school supporters believe that implementing TQM is likely to create more advantages to innovation. For example, Mahmud et al. (2019) investigated the factors of TQM and innovation in Malaysian SMEs (manufacturing industry). They found not support between TQMinnovation. Despite innovation is able to influence as a mediator between TQM and performance. Nevertheless, they monition that TQM-innovations in organizations still play an important role in improving performance. Escrig-Tena et al., (2019) did not find a significant direct association between soft QM dimensions (Closer to the customer, Closer to the supplier, increased training, Open organization, Employee empowerment) and (product and process innovation). They explained to encourage adopting QM practices in order to sustain and contribute to innovation performance, although in different ways, and its initiative that could guide future decisions. At 418 Australian manufacturing companies by Singh and Smith (2004) did not find sufficient statistical evidence to suggest that TQM was linked to the performance of innovation in companies and suggested that there could be a more complex relationship between these concepts. MorenoLuzon et al. (20013) a survey carried out on a sample of 72 Spanish (Valencia region) furniture and textile sectors. They find did not show a positive association between TOM principles and radical innovation. Moreover, they argued that TQM and innovation are still open to new perspectives. Similar findings by Jiménez-Jiménez et al. (2019) revealed that TQM practices do not indicate a significant impact upon process innovation and product a survey of 706 Spanish CEOs, (Approximately 58\% of the sample manufacturing industries). These results suggest that in the early stages of implementing a TQM system when companies begin to implement the technical aspects of TQM, they will have a very weak impact on innovation. This can be explained by the fact that focusing on routine and controlling flaws will reduce creativity, and thus innovation. Yusr et al., (2017) did not found a direct influence on innovation through quality management indicators. However, they emphasized that there is still a need to apply TQM practices to enhance innovation by contributing to building the necessary capabilities that enhance innovation. Finally, Antunes et al.'s (2018) findings indicate that small and mediumsized Portuguese companies not support. They suggested that organizations that implement TQM will be successful in the definition of innovative strategies. 


\subsection{Theoretical Framework}

Researchers have identified and mentioned the importance of TQM dimensions as a critical factor of innovation at the organizational level and tend to be more innovative. In addition, based on the given theory resource-based view (RBV) and literature review a conceptual framework is built. The search has been proposed to examine the influence of six dimensions TQM toward the product and process innovation perspectives at Jordanian manufacturing organizations. The conceptual framework consists of six variables, in which independent variables are "Leadership, People Involvement, Customer Focus, Processes Management, Suppliers Support and Design of Products "while the dependent variable is product and process innovation perspectives at Jordanian manufacturing organizations. Therefore, the Hypothesis of this study is:

H0: TQM affects manufacturing organization's product and process innovation perspectives.

H1: Top management affects manufacturing organization's product and process innovation perspectives.

H2: People involvement affects manufacturing organization's product and process innovation perspectives.

H3: Customer focus affects manufacturing organization's product and process innovation perspectives.

H4: Processes management affects manufacturing organization's product and process innovation perspectives.

H5: Suppliers support affects manufacturing organization's product and process innovation perspectives.

H6: Design of products affects manufacturing organization's product and process innovation perspectives.

\section{Methodology}

In this study, the researcher used an appropriately organized quantitative questionnaire to cover all aspects of TQM and Innovation Management that were discussed in the previous sections. The survey was conducted on 270 manufacturing in Amman establishments with ISO 9001: 2001 certifications (Ministry of Industry and Carpentry).The questionnaire is designed to obtain information from senior managers and production or managers and quality managers in Jordanian manufacturing organizations. The author personally visited each company to meet and asked managers to fill out the questionnaire with his presence in order to increase the reliability of the answers. Visited manufacturing organizations, which cover electronic / electrical appliances, machinery, medical, food, textile, chemicals, etc. 143 questionnaires were filled out only because many managers claim operators or come back after two days or a week, etc. To ensure content validity, the author conducted an extensive literature review past to develop the measurement instrument items of TQM dimensions and innovation (Product Innovation, Process Innovation) (Antunes et al., 2018; Arrfou, 2019; Jiménez-Jiménez et al., 2019; Kafetzopoulos et al., 2015; Kanji, 1996; Prajogo \& Sohal, 2004; Taddese, 2017; Yusr et al., 2017). The questionnaire was pre-tested by six managers of manufacturing enterprises to verify that the conceptual and practical perspectives identified by the researcher are appropriate for Jordanian manufacturing organizations, and that the terminology used is understood by all of them. The questionnaire was pilot-tested tested by ten academics and revised as needed. However, User responses were received from 123 manufacturing organizations resulting in a response rate of $49.3 \%$. Rate of survey responses Number of manufacturing organizations visited 249 Total responses 138 Invalid responses 15 Usable final responses 123 Usable response rate (\%) 49.3. The TQM dimensions in this study depend on the six dimensions of TQM, which were adopted from previous studies (Prajoge \& Sohal, 2004, 2006; Riillo, 2014), the six dimensions are (Leadership (LD), People Involvement (PI), Customer Focus (CF), Processes Management (PM), Suppliers Support (SS) and Design of Products (DP)). Thus, a total of 37 statements have been developed, and data are measured with a 5-point Likert scale ranging from $1=$ strongly disagree to $5=$ strongly agree. Measures of innovation have been derived (Product Innovation (PN) and Process Innovation (PIR)) and adapted from several studies (Al-Shourah \& Al-Shourah 2020; Altawallbeh et al., 2015; Hoang et al. 2006; Ooiet al., 2012; Riillo, 2014; Singh \&Smith 2004). Nine phrases were developed according to this construct, respondents (managers) are asked to indicate their views on the innovation in their organizations based on a five-point Likert scale $(1=$ strongly disagree; $2=$ Disagree; $3=$ Neutral; $4=$ Agree. $5=$ strongly agree).

\section{Findings}

\subsection{Profile of respondents}

Fig. 1 shows that the respondent's majority (89) were male compared to $11 \%$ who were female.

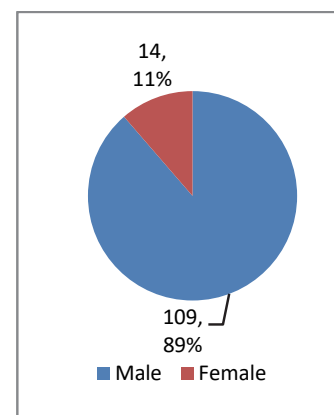

Gender

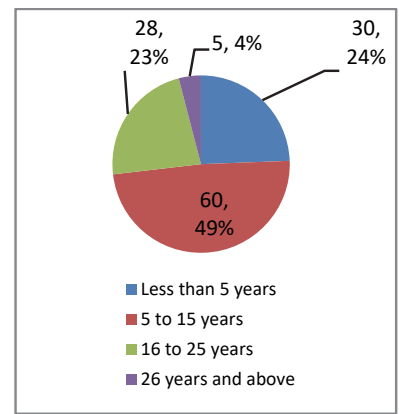

Experience

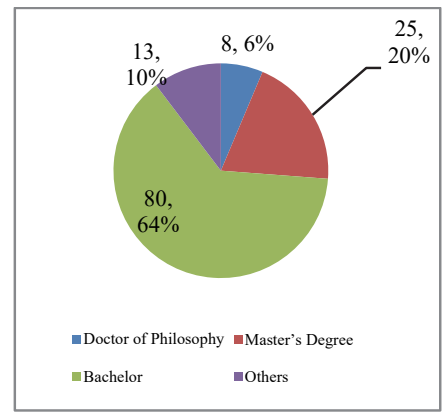

Educational background

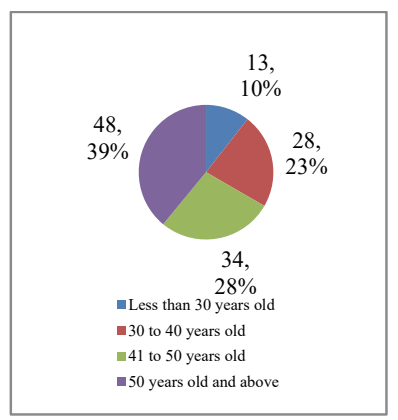

Age

Fig. 1. Personal characteristics of the participants 
The groups of age (41- 50) and (50 years old and above) show a cause for over two-thirds of the sample (67\%). However, this ratio is almost equal to the Position of Current of the same groups. Concerning the divide of participants by Education Level, table 3 displays that the majority of the respondents $65 \%$ (80) were Bachelor, 20\% (25) were Master. For experience less and more than five years, the result was $24 \%$ and $65 \%$ frequently.

\subsection{Reliability}

The Cronbach Alpha is used to measure reliability, which is the degree of consistency of the indicators associated with each variable. Therefore, Tables 1 and 2 illustrate the results of Cronbach Alpha for the TQM and innovation dimensions. However, the Cronbach alpha is accepted once it exceeds 0.70. This might drop to 0.60(Hair et al., 2006). In general, the reliability scale reached a minimum value of 0.73 , which confirms that the measuring instrument is reliable.

\subsection{Confirmatory Factor Analyses}

\subsubsection{Innovation Dimensions}

The CFA showed on innovation (Product, Process Innovation) displays the (Kaiser-Meyer-Okin) value of .83, exceeding the recommended value of above .60 (Hair et al., 2006) and the (Barlett's test of sphericity) was highly significant ( $\mathrm{p}=.00)$, supporting the factorability of the correlation matrix this factor accounted for 81.05 percent of the total variance in items. As shown in Table 4 and 2, Table 4 and 3, the loading factors are between .79 and .91. The Cronbach's Alpha for this factor is .91 , which indicates high reliability. Correlations from item to total revealed that removing any component would not increase from alpha beyond 0.87 , thus supporting the inclusion of all measurement elements in this study.

\section{Table 1}

Factor analyzes for Innovation Dimensions

\begin{tabular}{lccc}
\hline Items & Loadings & Reliability & Eigenvalues \\
\hline Product Innovation & & .89 & 7.58 \\
PN1 & .87 & & \\
PN2 & .69 & & \\
PN3 & .75 & .91 & 11.44 \\
PN4 & .70 & & 62.60 \\
Process Innovation & .87 & & \\
PIR1 & .77 & & \\
PIR2 & .74 & & \\
PIR3 & .70 & & \\
PIR4 & & & \\
\hline
\end{tabular}

\subsubsection{TQM Dimensions}

The CFA showed on TQM dimensions displays the KMO value of .81, exceeding the recommended value of .50 (Hair et al., 2006) and the (Barlett's test of sphericity) was highly significant $(p=.00)$, supporting the factorability of the correlationmatrix. This factor captured 75.09 percent of the total variance in the items. As shown in Table 3, FA between .90 and .78. The reliability (Cronbach's Alpha) for this factor is 0.86 , indicating high reliability. Correlations from item to total revealedthat removing any component would not increase from alpha beyond 0.86 , thus supporting the inclusion of all measurement dimensions in this study.

Table 2

Factor analyzes for TQM Dimensions

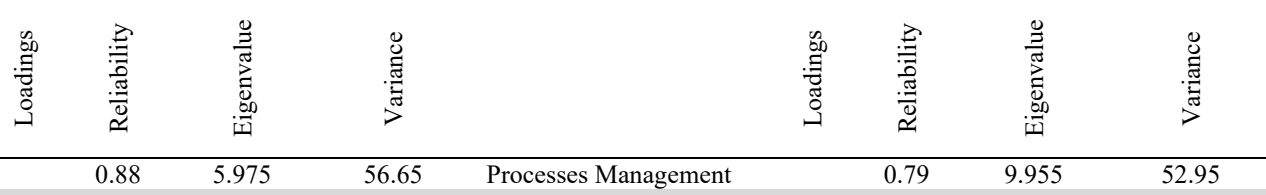

\begin{tabular}{|c|c|c|c|c|c|c|c|c|c|}
\hline Leadership & & 0.88 & 5.975 & 56.65 & Processes Management & & 0.79 & 9.955 & 52.95 \\
\hline LD1 & 0.89 & & & & PM1 & 0.88 & & & \\
\hline LD2 & 0.85 & & & & PM2 & 0.89 & & & \\
\hline LD3 & 0.79 & & & & PM3 & 0.83 & & & \\
\hline LD4 & 0.75 & & & & PM4 & 0.82 & & & \\
\hline LD5 & 0.69 & & & & PM5 & 0.8 & & & \\
\hline People Involvement & & 0.84 & 6.965 & 57.75 & PM6 & 0.74 & & & \\
\hline PI1 & 0.9 & & & & Suppliers Support & & & & \\
\hline OI2 & 0.87 & & & & SS1 & 0.77 & & & \\
\hline PI3 & 0.77 & & & & SS2 & 0.75 & & & \\
\hline PI4 & 73 & & & & SS3 & 0.74 & & & \\
\hline PI5 & 0.7 & & & & SS4 & 0.71 & & & \\
\hline PI6 & 0.78 & & & & Design of Products & & 0.83 & 5.275 & 49.67 \\
\hline Customer Focus & & 0.89 & 8.875 & 65.64 & DP1 & 0.92 & & & \\
\hline CF1 & 0.85 & & & & DP2 & 0.86 & & & \\
\hline CF2 & 0.73 & & & & DP3 & 0.73 & & & \\
\hline CF3 & 0.7 & & & & DP4 & 0.69 & & & \\
\hline CF4 & 0.68 & & & & & & & & \\
\hline CF5 & 0.67 & & & & & & & & \\
\hline
\end{tabular}




\subsection{Correlation analysis}

Table 4 indicates the correlation matrix between all the studied dimensions. The correlation coefficient shows the strength of the correlation between dimensions. Correlation is important if the p-value is less than 0.01 . There is a significant correlation between all the lists of study dimensions as shown in Table 4, out of 28 correlations, all R-Square values given in Table 4 are less than 0.9. Hare et al. (2006) suggested that to ensure that there are no multiple linear relationships; the correlation value should not exceed 0.90. As shown in Table 4, the highest parameter value is 0.857 (People Involvement with Customer Focus) which is smaller than 0.90 . Hence, no multiple linear relationships were found in this study.

Table 3

Correlations of Pearson Dimensions

\begin{tabular}{cllllll}
\hline & LD & PI & CF & PM & SP & PD \\
\hline LD & 1.00 & & & & & \\
PI & $0.847^{* *}$ & 1.00 & & & & \\
CF & $0.757^{* *}$ & $0.733^{* *}$ & 1.00 & & & \\
PM & $0.787^{* *}$ & $0.798^{* *}$ & $0.857^{* *}$ & 1.00 & & \\
SP & $0.778^{* *}$ & $0.633^{* *}$ & $0.788^{* *}$ & $0.822^{* *}$ & 1.00 & 1.00 \\
DP & $0.667^{* *}$ & $0.678^{* *}$ & $0.801^{* *}$ & $0.802^{* *}$ & $0.754^{* *}$ & $0.678^{* *}$ \\
PI & $0.667^{* *}$ & $0.678^{* *}$ & $0.801^{* *}$ & $0.802^{* *}$ & $0.754^{* *}$ & 1.00 \\
PIR & $0.667^{* *}$ & $0.678^{* *}$ & $0.801^{* *}$ & $0.802^{* *}$ & $0.754^{* *}$ & $0.578^{* *}$ \\
\hline
\end{tabular}

\subsection{Multiple Regression Analysis}

To test the relationships between TQM dimensions and innovation types within Jordanian manufactory, the Regression linear analysis was performed on predicted factors and innovation types. Table 4 and model summary exhibitions that the relationship between dimensions of TQM and innovation (Product Innovation, Process Innovation) is significant $(\mathrm{F}=$ 33.807; Sig. = .00). The $\mathrm{R}^{2}$ indicated that the influence of TQM dimensions is accounted for $73 \%$ of the variation in innovation types. Of all the dimensions of TQM inclusive in the equation of the regression, five dimensions appeared as significant predictors of innovation (product, process innovation). These are Leadership, People Involvement, Customer FocusProcesses Management and Design of Products. Therefore, hypotheses H1, H2, H3, H4 and H6 are supported. This leads to the conclusion that Leadership, People Involvement, Customer FocusProcesses Management and Design of Productsare positively related to innovation (product, process innovation). Supplier support is found that no significant influence on innovation types. Based on these results, hypotheses H 5 was rejected

\begin{tabular}{|c|c|c|c|c|c|}
\hline \multicolumn{6}{|c|}{ Model Summary } \\
\hline Model & $\mathrm{R}$ & R Square & Adjusted R Square & $\begin{array}{l}\text { d. Error of the } \\
\text { Estimate }\end{array}$ & Durbin-Watson \\
\hline 1 & $.389(a)$ & .151 & .142 & .74699 & 1.391 \\
\hline
\end{tabular}

Predictors: (Constant), mean_TQM dimensions, B -DV: mean_innovation types

Table 4

Summary of Multiple Regression Analysis for Factors TQM (N=95)

\begin{tabular}{lccccccc}
\hline & B & Std. Error & Beta & T & Sig & Tolerance \\
\hline 1 (constant) & 275 & 304 & & 915 & 368 & \\
Leadership & .060 & .060 & .011 & 2.082 & .090 & .331 \\
People Involvement & .355 & .084 & .484 & 3.234 & .000 & .407 & .820 \\
Customer Focus & .057 & .068 & .075 & .571 & .002 & .451 & .24 \\
Processes Management & .459 & .082 & .246 & 1.917 & .001 & .550 \\
Suppliers Support &. .166 & .055 & .132 & 4.252 & .004 & .507 \\
Design of Products & .156 & .084 & .264 & 3.244 & .000 & .407 & 2.795 \\
\hline
\end{tabular}

$\mathrm{DV}=\mathrm{QP} \mathrm{R}=.848$ (a) $\mathrm{R}=.73 \mathrm{~F}=33.807$, Sig=.000. Note: Sig levels:***p $<.00 ; * * \mathrm{p}<.01 ;{ }^{*} \mathrm{p}<.05$

\section{Discussion}

The outcomes of multiple regression analyses indicate that a TQM dimension has an important and positive relationship with innovation (Product, Process Innovation) in the Jordan manufacturing organizations. Our findings generally show that six dimensions of TQM "leadership, People Involvement, customer focus, operations management, supplier support, and product design" have a rather positive impact on the innovation of the surveyed at Jordanian manufacturing organizations. Our findings also show that Suppliers Support has an unimportant relationship with innovation. In other words, "TQM facilitates the development of innovation in organizations through coordinated management practices". On the other hand, TQM contributes to coordinating innovation initiatives in various organizational functions, especially the innovation process and product innovation (Taddese, 2017). Quality and innovation are two strategies. Two complementary allow companies to face fierce competition and maintain their competitive advantage (El Manzani et al., 2019).

The results of the study discovered that leadership commitment is found to be significant to affect the innovation (product, process innovation) in the Jordanian Manufacturing Organizations. This finding indicates that the Organizations' 
Leadership is committed and support to the implementation of TQM in their Manufacturing Organizations which reflect that they are aware of the important role of leadership in implementing TQM philosophy to improve and enhance innovation (product, process innovation) and satisfy customer expectations (Rad, 2006; Prajogo, 2005). However, the study's findings investigation demonstration a clear impact of implementing a TQM philosophy on innovation (product, process innovation), which is stable with practical works showed by some authors (Jiménez-Jiménez et al., 2019, El Manzani et al., 2019). However, this study found significant relationship between people Involvement and product and process innovation perspectives. In other words, People Involvement promotes the development of innovative activities manufacturing organizations, and that is according to a search conducted by Sahoo et al. (2020) and Antunes et al., (2018). In addition, Customer focus has a positive impact on product and process innovation in Jordanian manufacturing organizations. Thus, the findings support the initial idea that "a customer focus, connected with obtaining information about current and future customer needs, benefits the organization's inclination towards product and process innovation" (Hung et al., 2011). In addition, obtaining and analyzing Information about the customers is one of the most frequently used implementations of TQM practices (Alshourah, 2020). Several studies in the literature of TQM match the current study results such as Kanapathy et al., (2017) and Taddese (2017) in which the researchers have shown focus on customerswere found to be significant to enhance product and process innovation.

Processes management found that there are positive research-related innovative activities and (product and process innovation). The results show that the operations management approach is underpinned and optimized for establishing and maintaining the R\&D department, developing new technologies, innovation in product packaging, customer contact techniques, distribution methodologies, and pricing policies. The implementation of a quality management system in accordance with these standard forces the improvement of the processes necessary for the quality management system and their implementation throughout the organization, thus being reflected in the development of product and process innovation strategies. These search findings are consistent with previous research (Antunes et al., 2018, Taddese, 2017, Prajogo\& Hong, 2008). On the other side, theconsequencerevealed that in this study suppliers Support negative with product innovation and process innovation. On this aspect, a futher explanation is important. This result seems to contradict previous studies, which indicate that the relationship between suppliers and innovation activities in organizations is positive. However, the expected interpretation of this finding is that the relationship with suppliers subjects the organization to changes in product and process with a view to better utilization/integration of goods and provided by the supplier. In this context, relationships with suppliers may discourage innovation activities for organizations. These results are consistent with previous research (Augusto et al., 2015). As a final dimension, this study found a positive relation with product design and product and process innovation. The use of techniques and quality tools can help manufactory origination's monitor emerging and changing customer needs toward high product innovation and process innovation. This result found and supports previous studies such as those done by Sahoo, (2020) who found thata positive relation with product design and product and process innovation. He suggests that designing quality product could be an important foundational element for product innovation, ensuring faster and more effective translation of new ideas into product features and technical specifications that values customer's requirements. Another study by Antunes et al., (2018) found that a positive relation with product design and product innovation and process innovation in the Manufacturing small and medium-sized Portuguese companies. They suggest that the manufacturing organizations ability to design quality into products is a critical capability for product and process innovation.

\section{Managerial implications}

The positive relationship between TQM dimensions and product and process innovation procedures demonstrates the importance of each of these practices for improving and developing the manufacturing organizations. Leaders can use this updated model periodically to analyze the position of their manufacturing and the success of product development and update processes in the quality management trip. They can also investigate the effects of TQM dimensionson measures of innovation: product innovation and process innovation in order to evaluate the success of TQM dimensions. The study revealed that the positive relationships between the dimensions of total quality management and innovation measures should encourage senior management leaders in organizations to participate in the best quality planning for the goals of the organizations, to determine the resources and capabilities in time, effort and capital to implement the dimensions of total quality management in organizations, which leads to improving procedures and raising The performance of organizations and a better competitive position and better meet the needs and desires of customers. The results of this study reveal that the customer focus of senior management leaders, operations management, people management, and product design can be combined to improve product and process innovation. Thus, customer expectations are better met when the manufacturer produces an innovative and high-quality product. For this reason, continuous improvement is a high priority, and it must be implemented in the organization's systems and employee behavior (Manders et al., 2016).In addition, Survey techniques such as consumer responses and complaint analysis should be focused on regular times to ensure and confirm that customer needs and expectations are met, which will enhance and improve the innovation activities. Finally, the outcome of this research provides valuable insight regarding the dimensions of TQM and innovation from the perspective of the Jordanian manufacturing sector. The Jordan Manufacturing Organizations should focus on implementing TQM dimensions if they really want to improve and enhance the quality of their products and be able to compete in the market of international. The findings can assist academics, policymakers, managers, and companies that want to boost and support TQM dimensions in Jordan. 


\section{Search of future}

Mediation linkage with TQM dimensions and measures of innovation can also be evaluated in future search. Innovation measure such as marketing, Organizational, and Management innovation can be comprised in future search. The moderating effects of elements such as organization income, organization size and organization type can be studied to analyze relationships between these factors as well. In prospective studies, comparative studies can be made between the multigroup of service and manufacturing organizations. The outcomes of this search were created on cross-sectional data from the related Jordan manufacturing organization. Future studies may highlight the longitudinal design of the survey. Moreover, the outcomes of this search are limited to Jordan manufacturing organizations, but a similar search may be studied in other countries to evaluate if the structural model fits into their systems, which in turn gives further validation of the recommended model.

\section{Conclusion}

This search aimed to test the existing suggestions in the literature about the importance of TQM dimensions in the process and product innovation in the Jordanian manufacturing organizations. In general, the results obtained in this study support the results of previous studies and allow us to conclude that the adoption of TQM has an impact on the process and product innovation. However, as previously mentioned and clarified; TQM in its different dimensions has different effects on the innovation of manufacturing organizations. The analysis of the results shows that the design of products and people Involvement and enhances innovation. In contrast, the results did not demonstrate any effect on the Suppliers Support on the process and product innovation. In general, it can be concluded that the adoption of TQM dimensions plays a major role in innovation activities and the relationship it will be large and growing, indicating a gradual growth trend. The relationship is always positive and growing with high levels of total quality in the manufacturing organizations.

\section{Acknowledgement}

The Author is grateful to the Zarqa university, Jordan for the full financial support granted to this research project.

\section{References}

Alshourah, S. (2020). Total quality management practices and their effects on the quality performance of Jordanian private hospitals. Management Science Letters, 11(1), 67-76.

Al-Shourah, S. Al-Shourah, A, A. (2020). An examination between total quality management and hotel financial performance: Evidence from Jordanian international hotels. Information Management and Decisions Séances.

Abdullah, A. B. (2013). The influence of "soft" and "hard" total quality management (TQM) practices on total productive maintenance (TQM) in Jordanian manufacturing companies. International Journal of Business and Management, 8(21), 1.

Abdullah, A. B., Dahiyat, S. E., \& Matsui, Y. (2019). Lean management and innovation performance. Management Research Review, 42(2), 239-262.

Abu-Salim, T. A., Sundarakani, B., \& Lasrado, F. (2019). The relationship between TQM practices and Organisational innovation outcomes. The TQM Journal, 31(6), 874-907.

Abrunhosa, A., \& Sá, P. M. E. (2008). Are TQM principles supporting innovation in the Portuguese footwear industry?. Technovation, 28(4), 208-221.

Allan, A. J. A., Kasim, N. A. B. A., Mustapha, M. B., \& Shah, S. B. M. (2018). An overview of Jordanian manufacturing sector in light of current regional political situation.

Altawallbeh, M., Soon, F., Thiam, W., \& Alshourah, S. (2015). Mediating role of attitude, subjective norm and perceived behavioral control in the relationships between their respective salient beliefs and behavioral intention to adopt elearning among instructors in Jordanian universities. Journal of Education and Practice, 6(11), 152-159.

Antunes, M. G., Quirós, J. T., \& Justino, M. D. R. F. (2017). The relationship between innovation and total quality management and the innovation effects on organizational performance. International Journal of Quality \& Reliability Management, 34(9), 1474-1492.

Arrfou, H. (2019). New business model of integration practices between TQM and SCM: the role of innovation capabilities. Problems and Perspectives in Management, 17(1), 278-288.

Business, D. (2020). Comparing Business Regulation in 190 Economies. International Bank for Reconstruction and Development. The World Bank. Washington, 135.

Camisón, C., \& Puig-Denia, A. (2016). Are quality management practices enough to improve process innovation?. International Journal of Production Research, 54(10), 2875-2894.

Chandy, R. K., \& Tellis, G. J. (1998). Organizing for radical product innovation: The overlooked role of willingness to cannibalize. Journal of Marketing Research, 35(4), 474-487.

Council, E. P. (2018). Jordan: Economic Growth Plan 2018-2022. Amman, Jordan, 116.

Di Benedetto, C. A., DeSarbo, W. S., \& Song, M. (2008). Strategic capabilities and radical innovation: an empirical study in three countries. IEEE Transactions on Engineering Management, 55(3), 420-433. 
El Manzani, Y., Sidmou, M. L., \& Cegarra, J. J. (2019). Does IS0 9001 quality management system support product innovation? An analysis from the sociotechnical systems theory. International Journal of Quality \& Reliability Management, 36(6), 951-982.

Escrig-Tena, A. B., Segarra-Ciprés, M., García-Juan, B., \& Beltrán-Martín, I. (2018). The impact of hard and soft quality management and proactive behaviour in determining innovation performance. International Journal of Production Economics, 200, 1-14.

Feng, J., Prajogo, D.I., Chuan Tan, K. and Sohal, A.S. (2006). The impact of TQM practices on performance: a comparative study between australian and singaporean organizations. European Journal of Innovation Management, 9 (3), $269-278$.

Hoang, D. T., Igel, B., \& Laosirihongthong, T. (2006). The impact of total quality management on innovation. International Journal of Quality \& Reliability Management, 23(9).

Hung, R. Y. Y., Lien, B. Y. H., Yang, B., Wu, C. M., \& Kuo, Y. M. (2011). Impact of TQM and organizational learning on innovation performance in the high-tech industry. International Business Review, 20(2), 213-225.

Jiménez-Jiménez, D., Martínez-Costa, M., \& Para-Gonzalez, L. (2019). Implications of TQM in firm's innovation capability. International Journal of Quality \& Reliability Management, 37(2), 279-304.

Kafetzopoulos, D., Gotzamani, K., \&Gkana, V. (2015). Relationship between quality management, innovation and competitiveness. Evidence from Greek companies. Journal of Manufacturing Technology Management.

Kanji, G. K. (1996). Can total quality management help innovation?. Total Quality Management, 7(1), 3-10.

Kanapathy, K., Bin, C. S., Zailani, S., \& Aghapour, A. H. (2017). The impact of soft TQM and hard TQM on innovation performance: the moderating effect of organisational culture. International Journal of Productivity and Quality Management, 20(4), 429-461.

Kim, D. Y., Kumar, V., \& Kumar, U. (2012). Relationship between quality management practices and innovation. Journal of Operations Management, 30(4), 295-315.

Krajcsák, Z. (2019). Implementing open innovation using quality management systems: The role of organizational commitment and customer loyalty. Journal of Open Innovation: Technology, Market, and Complexity, 5(4), 90.

López-Mielgo, N., Montes-Peón, J. M., \& Vázquez-Ordás, C. J. (2009). Are quality and innovation management conflicting activities?. Technovation, 29(8), 537-545.

Mahmud, N., Hilmi, M. F., Mustapha, Y. A. A., \& Abu Karim, R. (2019). Total quality management and SME performance: the mediating of innovation in Malaysia. Asia-Pacific Management Accounting Journal (APMAJ), 14(1), $201-217$.

Martinez-Costa, M., \& Martínez-Lorente, A. R. (2008). Does quality management foster or hinder innovation? An empirical study of Spanish companies. Total Quality Management, 19(3), 209-221.

Ministry of Industry and carpentry.(2019). Annual Report.

https://www.mit.gov.jo/ebv4.0/root_storage/ar/eb_list_page/trade_mag_2018_2020.pdf

Manders, B., de Vries, H. J., \& Blind, K. (2016). ISO 9001 and product innovation: A literature review and research framework. Technovation, 48, 41-55.

Maistry, K., Hurreeram, D. K., \& Ramessur, V. (2017). Total quality management and innovation. International Journal of Quality \& Reliability Management, 34(3), 418-437.

Moreno-Luzon, M. D., Gil-Marques, M., \& Valls-Pasola, J. (2013). TQM, innovation and the role of cultural change. Industrial Management \& Data Systems, 113(8), 1149-1168.

Moura E Sá, P., \& Abrunhosa, A. (2007). The role of TQM practices in technological innovation: The Portuguese footwear industry case. Total Quality Management \& Business Excellence, 18(1-2), 57-66.

Pekovic, S., \& Galia, F. (2009). From quality to innovation: Evidence from two French Employer Surveys. Technovation, 29(12), 829-842.

Perdomo-Ortiz, J., González-Benito, J., \& Galende, J. (2006). Total quality management as a forerunner of business innovation capability. Technovation, 26(10), 1170-1185.

Prajogo, D. I., \& Sohal, A. S. (2004). The multidimensionality of TQM practices in determining quality and innovation performance - an empirical examination. Technovation, 24(6), 443-453.

Prajogo, D. I., \& Sohal, A. S. (2006). The integration of TQM and technology/R\&D management in determining quality and innovation performance. Omega, 34(3), 296-312.

Ooi, K. B., Lin, B., Teh, P. L., \& Chong, A. Y. L. (2012). Does TQM support innovation performance in Malaysia's manufacturing industry?. Journal of Business Economics and Management, 13(2), 366-393.

Riillo, C. A. F. (2014). Quality management and innovation: a review of quantitative studies. International Journal of Productivity and Quality Management, 14(4), 441-456.

Sadikoglu, E., \& Zehir, C. (2010). Investigating the effects of innovation and employee performance on the relationship between total quality management practices and firm performance: An empirical study of Turkish firms. International Journal of Production Economics, 127(1), 13-26.

Shan, A. W., Ahmad, M. F., \& Nor, N. H. M. (2016, November). The mediating effect of innovation between total quality management (TQM) and business performance. In IOP Conference Series: Materials Science and engineering (Vol. 160, No. 1, p. 012011). IOP Publishing.

Sahoo, S. (2019). Quality management, innovation capability and firm performance. The TQM Journal, 31(6), 1003-1027.

Saleh, R. A., \& Sweis, R. J. (2017). The relationships between soft/hard total quality management practices and operational performance in Jordanian manufacturing organisations. International Journal of Management Concepts and Philosophy, 10(4), 345-377. 
Taddese, F. (2017). Application of TQM for Innovation: An Exploratory Research of Japanese, Indian and Thailand Companies. International journal of innovation and technology management, 14(04), 1750020.

Trading economics, Historical Indicters, Jordan manufacturing. (2020). https://tradingeconomics.com/jordan/gdp-frommanufacturing.

Yusr, M. M. (2016). Innovation capability and its role in enhancing the relationship between TQM practices and innovation performance. Journal of Open Innovation: Technology, Market, and Complexity, 2(1), 6.

Zehir, C., Ertosun, Ö. G., Zehir, S., \& Müceldilli, B. (2012). Total quality management practices' effects on quality performance and innovative performance. Procedia-Social and Behavioral Sciences, 41, 273-280.

Zeng, J., Zhang, W., Matsui, Y., \& Zhao, X. (2017). The impact of organizational context on hard and soft quality management and innovation performance. International Journal of Production Economics, 185, 240-251.

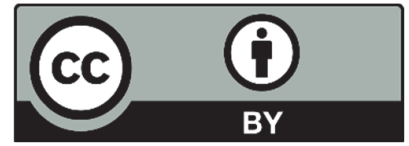

(C) 2021 by the authors; licensee Growing Science, Canada. This is an open access article distributed under the terms and conditions of the Creative Commons Attribution (CC-BY) license (http://creativecommons.org/licenses/by/4.0/). 